\title{
Choices for tree conservation
}

\author{
Sara Oldfield
}

$\mathrm{T}$

en years ago the first global evaluation of the conservation status of tree species was published. The World List of Threatened Trees (Oldfield et al., 1998) estimated that 10\% of the world's tree species were threatened with extinction. Given the ecological, economic and cultural importance of trees this was clearly of great concern. It was hoped that the publication of The World List of Threatened Trees would galvanize action and there has been some conservation progress for individual trees and their habitats, at least in part stimulated by the global evaluation. But as yet the conservation responses for trees and the allocation of resources are inadequate given the scale of the extinction crisis.

This issue of Oryx reflects on the choices available for the conservation of trees and highlights the complexity of solutions. Understanding the threats to trees and the links between these threats are necessary steps in conservation planning. Of course the threats are sometimes speciesspecific, as in the case of over-harvesting of a particular tree product, or more general as a result of forest degradation and clear-felling. The impact on individual tree species of a combination of threats will differ according to the biology and autecology of the species but as yet this basic information is not available for the majority of tree species. The conservation responses for trees are consequently relatively blunt tools. Documented examples of successes, failures and possibilities, as provided by the authors of the articles in this issue, are clearly of great value in guiding and promoting further action.

Conservation through sustainable use and trade in timber and non-timber forest products has been widely presented as the dream ticket for the conservation of forests and their trees, providing both ecological security and livelihood options for the millions of people who live in or around forest ecosystems. In reality, as discussed by Newton (2008), Gubbi \& MacMillan (2008) and Schulze et al. (2008), sustainable use of forest resources is not an easy option. The so-called use it or lose it argument for conserving forests is compromised by the fact that trade in forest products rarely, if ever, provides sufficient financial returns to protect the forest against other threats (Newton, 2008). This is the case even where high-value timber is harvested for the international market, and considerably more so where non-timber forest products are harvested. Gubbi \& MacMillan (2008) point out that collecting non-timber forest products is hard work. They

SARA OldFIELD Botanic Gardens Conservation International, Descanso House, 199 Kew Road, Richmond, Surrey, TW9 3BW, UK. E-mail sara.oldfield@ bgci.org

found that the collectors of damar resin from Canarium strictum and wild spices from trees in the Periyar Tiger Reserve of the Western Ghats in India would not continue harvesting these non-timber forest products, despite recent changes in legislation to allow them to do so, if alternative livelihoods from agriculture could be provided.

True sustainable forestry as promoted by the Forest Stewardship Council should take into account ecological, economic and social criteria. Based on the application of these criteria, sustainability can be assessed and forest products from sustainably managed sites certified for the market-place. As pointed out by Schulze et al. (2008), who analyse forest certification in Amazonia, given technical uncertainties, undervalued timber, and unfair competition with illegal logging, a generous definition of sustained timber yield may be all that is realistic for now. On this basis a continuous supply of timber is assured but not necessarily the survival of populations of valuable timber species, and undoubtedly not the survival of other tree species within the forest.

Measures can be taken to improve the likelihood of successful sustainability of individual species, as indicated by Jensen \& Meilby (2008). This case study concludes that the harvesting of a commercially valuable non-timber forest product, agarwood, found within diseased trees of the Critically Endangered Aquilaria crassna, can be improved by training in selection of trees for harvesting linked with improved access to profitable markets. Knowledgeable harvesters who can target trees containing agarwood are unlikely to harvest indiscriminately, thus leaving populations of the species relatively intact.

Ideally, for each globally threatened tree species a package of conservation measures is required. In situ protection in natural habitats is clearly the preferred option. In addition to national parks and nature reserves conservation stands within land set aside for commercial forestry, as with the Virgin Jungle Reserves of Malaysia where patches of intact forest have been established for the conservation of forest genetic resources and research, will become increasingly important, as will trees within agricultural land. For species with useful products in situ protection can be enhanced by local plantation development, as is the case for Abies guatemalensis, which has become important as a Christmas tree in the cities of Guatemala (Strandby Andersen et al., 2008). Ex situ conservation as a back-up measure is an achievable and pragmatic insurance policy for tree species, and is particularly important given the uncertainty for survival of species in the face of climate change and the spread of pests and diseases such as Sudden Oak Death. Ex situ 
conservation populations should of course be genetically representative and planned to support local plantations for useful species and restoration of species and habitats.

Working together, Fauna \& Flora International and Botanic Gardens Conservation International are implementing the Global Trees Campaign, which aims to save globally threatened trees and their habitats. Various approaches, including both in situ and ex situ conservation, restoration in natural habitats, and sustainable forest management are being implemented for a range of flagship tree species. These include magnolias in China, Colombia and Cuba, agarwood species in Cambodia, oaks in the USA, and rosewoods in Central America. Scaled up, this Campaign should begin to achieve the impact that was intended when it was first launched 10 years ago. The involvement of an increasing range of botanic gardens, arboreta, forestry departments and other partners, partially in response to updated IUCN Red Lists for selected tree groups, is an encouraging sign. Overall, however, there needs to be much more financial and technical support for saving trees, building on all available conservation options.

Currently 1,002 tree species are listed as Critically Endangered on the IUCN Red List, 26 more than when The World List of Threatened Trees was published. Many of these species have been reduced to $<50$ individuals in the wild and may already be functionally extinct, with isolated individuals persisting in forest fragments. Urgent action is needed to conserve and restore these species and to prevent more species slipping into the Critically Endangered category. In the longer term issues that will need to be considered are how to value the full range of services provided by trees, over and above the financial value of specific products, and how to provide incentives for their long-term conservation. Additionally it will be important to promote an appreciation of the diversity of tree species not all can be flagships but each individual species has an important and unique function in its natural ecosystem.

\section{References}

Gubbi, S. \& MacMillan, D.C. (2008) Can non-timber forest products solve livelihood problems? A case study from Periyar Tiger Reserve, India. Oryx, 42, 222-228.

Jensen, A. \& Meilby, H. (2008) Does commercialization of a nontimber forest product reduce ecological impact? A case study of the Critically Endangered Aquilaria crassna in Lao PDR. Oryx, 42, 214-221.

Newton, A. (2008) Conservation of tree species through sustainable use: how can it be achieved in practice? Oryx, 42, 195-205.

Oldfield, S., Lusty, C. \& MacKinven, A. (1998) The World List of Threatened Trees. World Conservation Press, UNEP-WCMC, Cambridge, UK.

Schulze, M. Grogan, J. \& Vidal, E. (2008) Forest certification in Amazonia: standards matter. Oryx, 42, 229-239.

Strandby Andersen, U., Córdova, J.P.P., Nielsen, U.B., Olsen, C.S., Nielsen, C., Sørensen, M. et al. (2008) Conservation through utilization: a case study of the Vulnerable Abies guatemalensis in Guatemala. Oryx, 42, 206-213. 